\title{
Intelektualista w lagrze. Perspektywa Julija Margolina
}

\section{An intellectual in the Gulag. Yuliy Margolin's perspective}

\begin{abstract}
The aim of this article is to attempt to discuss the report of Yuliy Margolin from the Soviet Gulag. A Journey to the Land of $\mathrm{Ze}-\mathrm{Ka}$ is an original work, written from the perspective of a prisoner, who is mostly an intellectual, a philosopher, an excellent observer and interpreter of European reality. The author of the article tries to prove that for Margolin the superior value in the Gulag is the mind, which wins over emotions and thanks to that allows to preserve dignity and humanity. The analysis of identity, carried out by Margolin, allows us to read his testimony in the context of contemporary identity research in extreme situations, where instead of building up our own self, we are fighting for our moral values. As it turns out, the basic foundation of identity is freedom. The article also undertakes a preliminary analysis of Margolin's concept of hate as the most destructive force for the human individual and the intellect. The mind, according to Margolin, effectively defends freedom, and hate kills free thought, destroys goodness, and consequently leads to dehumanization. The research allows us to call Margolin a rationally thinking humanist, an intellectual who is against historical fatalism, who constantly analyses current events and human behaviour, without losing faith in the mind and the human individual.
\end{abstract}

Keywords: Yuliy Margolin, intellectual, Soviet Gulag, The Journey to the Land of Ze-Ka, theory of hatred

Agnieszka Lenart, Uniwersytet Śląski w Katowicach, Sosnowiec - Polska, agnieszka.lenart@ us.edu.pl, ORCID ID: https://orcid.org/0000-0002-7467-2788

Julij Margolin, więzień sowieckich łagrów, urodzony na Polesiu rosyjskojęzyczny twórca i filozof żydowskiego pochodzenia, reprezentuje, jak sam twierdzi, „postępową humanistyczną inteligencję Zachodu” (Margolin 167). Pisarz pochodzi z inteligenckiej rodziny, jest człowiekiem dobrze wykształconym, trudni się pracą umysłową, a podstawę jego światopoglądu tworzą jasno określone, typowe dla inteligenckiego etosu wzorce i wartości - odpowiedzialność moralna, poszanowanie wolności i godności człowieka (Abassy 26).

W tytule niniejszego tekstu nie bez powodu więc, zamiast słowa inteligent, używam określenia ,intelektualista”. Margolin, filozof ze stopniem doktora, pasjonat literatury rosyjskiej, teoretyzujący syjonista, jest przede wszystkim inte- 
lektualistą, inteligentem z misją (Abassy 38), człowiekiem „o dużej wiedzy i wybitnych zdolnościach umysłowych" (Wiśniakowska 408), filozofem z zacięciem literackim lub też niepospolitym umysłem z zacięciem filozoficznym (Sucharski 271), którego postawę, nawet w najtrudniejszych latach łagrowych doświadczeń, wyróżnia „przewaga intelektu nad emocjami” (Wiśniakowska 408). Pisarz przed wyjazdem do Palestyny czynnie angażował się w życie społeczne i polityczne, aktywnie działał w ruchu syjonistycznym, poświęcał się działalności wydawniczej, dużo publikował. Przemiany zachodzące w Polsce po 1939 roku sprzyjały wyostrzeniu jego intelektualnej dociekliwości. Margolin nie przestawał „rozpoznawać/diagnozować i nazywać problemów" (Abassy 21), które dotknęły Europę, coraz częściej omawiał przyczyny historycznej zawieruchy, poszukiwał sposobów rozwiązania europejskich problemów. W jego świadomości powstały wówczas pewne ramy teoretyczne, w których osadził własną koncepcję świata i człowieka, świata, który na jego oczach przeistaczał się w ,imperium zła” i człowieka, uwikłanego w antropologiczny eksperyment narzucania mu nowej tożsamości i kształtowania osobowości homo sovieticus (Suchanek 1999: 77). Poddany działaniom totalitarnej machiny filozof, najpierw aresztowany przez NKWD, a następnie wysłany „wędrującą trumną” aż po archangielskie bezkresy Rosji, już na samym początku tej trudnej drogi bacznie obserwował rzeczywistość, wówczas zaczął także pracę nad trylogią. W warunkach fizycznego i psychicznego zniewolenia opracował teorię kłamstwa, wolności i nienawiści. Tę ostatnią koncepcję omówię dokładniej w dalszej części artykułu, bowiem to właśnie rozum, wytyczający kierunek moich badań, jest w ujęciu autora-narratora Podróży ,jedynym przeciwnikiem” nienawiści (Margolin 282), fundamentu, na którym budowana jest nowa tożsamość człowieka „odczłowieczonego” (Margolin 104), jedyna ideologicznie poprawna osobowość homososa (Zinowiew 165-168). Tym, co najbardziej wyróżnia zeka intelektualistę spośród „obozowej masy”, jest nieustanna walka o utrzymanie statusu homo sapiens. Rozum, chociaż zdecydowanie szkodzi przetrwaniu w sowieckim „laboratorium ideologicznym” (Suchanek 1996: 12), chroni przed urzeczowieniem i całkowitą destrukcją. Doświadczenia Margolina zebrane w Podróży do krainy zeków (Путешествие в страну зэ-ка, 1952) (pierwsza, mocno zrewidowana przez cenzurę wersja wspomnień ukazała się w 1948 roku) potwierdzają bezkompromisowość sowieckiego systemu wobec człowieka i bezkompromisowość autora wobec ideologii totalitaryzmu komunistycznego, z którą jako świadek wydarzeń, pisarz i intelektualista walczył do śmierci w 1971 roku.

W walce o własną godność i w obronie milionów zniewolonych ludzi Margolin stosował inteligenckie metody protestu. Narzędziami sprzeciwu były, zamiast brutalnego zachowania, wulgaryzmów i zwykłego kopniaka - pióro i sztuka krasomówstwa. Ogromnym szacunkiem darzył Margolin literaturę. W objętym 
sowietyzacją Pińsku, zanim zrozumiał, że ma do czynienia z ,inkwizycją radziecką", która niebawem karze mu masowo niszczyć książki niezgodne z sowiecką ideologią, filozof zajmował się porządkowaniem zbiorów bibliotecznych, ratowaniem „cmentarzyska kultury” (Margolin 31). O pracy w pińskim archiwum pisał:

Poczułem się jak wśród diamentów, w pieczarze króla Salomona. Oczy mi się zaświeciły [...], zaczęliśmy stąpać po prawdziwych skarbach, muszę przyznać, że przez całe życie nie miałem pracy bardziej odpowiadającej moim skłonnościom (Margolin 31).

Margolin znał wagę dziedzictwa kulturowego i czuł się za nie odpowiedzialny, szczególnie w tak trudnym dla dziejów ludzkości okresie, wierzył w sensowność swojego twórczego i intelektualnego posłannictwa (Sucharski 269): „Należałoby także postawić pomnik nieznanej zniszczonej książki - pisze Margolin. Tej, którą zniszczyły ręce gnębicieli ducha, tej, którą zdusili w zarodku, i tej, której nie dopuścili do czytelników" (Margolin 315). Literaturę traktował jak świątynię, literaturę propagandową, bo z tą właśnie w sowieckiej Rosji spotykał się najczęściej, jako jej kategoryczne zaprzeczenie. $\mathrm{W}$ jego ocenie:

literatura Zachodu mówi otwarcie i śmiało o wszystkich wadach demokracji i wnosi światło w ciemne zakamarki, poddana cenzurze literatura ustroju niewolniczego milczy i stara się nie patrzeć tam, gdzie jest ciemno. Nie potrafi odpowiedzieć na oskarżenia inaczej, niż uciekając się do wyzwisk i negując fakty (Margolin 346).

Symbolem upadku najważniejszych wartości są książki niszczone przez cenzurę, palone, rzucane w błoto, przerabiane na skręty. Ludzie radzieccy, którzy niszczyli dzieła literackie i zabijali wolną myśl, byli najbardziej znienawidzonymi wrogami narratora. Odrazę, a jednocześnie współczucie Margolina budził „sowiecki masowy człowiek", zaanektowany bez reszty przez irracjonalny świat komunistycznej propagandy. Dzieła Lenina i Stalina, czytane z partyjnym instruktorem, świadczyły o upadku człowieczeństwa.

Sympatię i przyjaźń pisarza zyskiwali natomiast inteligenci, ludzie nauki (np. Maksik, doktor Maks Albertowicz Rosenberg - świetny chirurg czy Nikołaj - ukraiński nauczyciel z Dniepropietrowska, bibliofil, miłośnik słowa), którzy potrafili „czerpać najszczerszą rozkosz z literatury i ze sztuki” (Margolin 274). Kontakt z literaturą, sama myśl o kulturze wyznaczały Margolinowski horyzont przyszłości, chroniły przed „urzeczowieniem” (Ubertowska 36), były Adornowskim „błyskiem wolności” (Adorno, Horkheimer 95) czy wreszcie „azylem dla ludzkiej indywidualności" (Ubertowska 36).

Warto wspomnieć, że na przeciwległym biegunie obozowej społeczności klasyfikował Margolin urki - obozowych kryminalistów, ludzi bestie, żyjących dniem dzisiejszym. $Z$ pewnością w ocenie autora-narratora nie byli to wyzwoleni 
i zbuntowani artyści, o których pisał Aleksander Wat (Sucharski 313). Margolin traktował ich raczej jako osoby chwiejne, politycznie niebezpieczne, wygodne dla obozowych przywódców i niesprzeciwiające się reżimowi. Ich jedynym celem były osobiste korzyści. Urki w Podróży reprezentują najgorszą kategorię zeków złodziei i bandytów, ludzi moralnie okaleczonych, pozbawionych sumienia. Nie przeszkadzało to jednak autorowi, mimo jego zdecydowanej niechęci do urków, wypowiadać się o nich bez emocji, z Margolinowskim taktem.

Ważną część prowadzonej w Podróży narracji zajmuje refleksja natury tożsamościowej. Świadomość bycia humanistą, człowiekiem, który nie chce stać się ,,igraszką obcego żywiołu”, to jest przystać na propozycje bycia człowiekiem radzieckim (Margolin 282), sprawia, że narrator włącza tryb osobowościowej samokontroli, podejmuje ,wielowymiarowy sąd osobisty” (Kozielecki 325). Po pierwsze, wielowątkowo analizuje swoje położenie, po drugie analizuje swój stosunek wobec innych i innych wobec siebie, po trzecie, biorąc pod uwagę różne, zmienne okoliczności, w jakich się znajduje, stale weryfikuje swoje idem. Margolin ma świadomość, że w świecie okrutnego zniewolenia i moralnej pustki nie można przewidzieć swojego zachowania, że człowiek zezwierzęcony nie jest wierny sobie i swoim ideałom. O ile poddana totalitarnej presji tożsamość narratora-bohatera jest wystawiona na próbę i stale delikatnie ewoluuje, ostatecznie inteligencki etos chroni ją przed rozmyciem, pozwala zachować ludzką naturę i nie godzi się jej nagiąć do potrzeb nowej ideologii (Neuner 156). Wybrzmiewają w Margolinowskim tekście echa filozofii Paula Ricoeura. Margolin walczy o ciągłość siebie, traktuje ipse jako tożsamość nie daną, ale zadaną (Ricoeur 193), a nie ustając w stosowaniu metody samoopisu, czy też samooceny (Nikitorowicz 70), stale weryfikuje swoje ,ja”. Nawet w warunkach „łagrowego piekła” broni się przed tożsamościową dyfuzją, stawia zobowiązanie bycia sobą wobec siebie i wobec innych. Gwarancją ,sobości”, trwałego ,ja” jest, według pińskiego filozofa, uporządkowana samowiedza i ugruntowany świat wartości. Bycie sobą traktuje Margolin jako ciągłe odczuwanie w świecie własnej obecności, nawet jeśli jest to świat ,uniwersalnych nadludzi”, plastycznych do granic możliwości homo sovieticus (Zinowiew 163-168). Nie dziwi fakt, że sytuacja kryzysowa/graniczna (Sariusz-Skąpska 103), w jakiej znalazł się autor, rodzi w nim potrzebę kontrolowania własnej podmiotowości, ponownego obrania pewnej postawy wobec świata i wydarzeń, które zakłócają ciągłość bycia (Bittner 19). Margolin z pokorą więc poszukuje prawdy o sobie i świecie: „Cóż o sobie wiemy, dopóki nie poddano nas próbie?” (Margolin 142) - pyta narrator. Łagier, podobnie jak u Sołżenicyna i Czapskiego, jest w Podróży sprawdzianem „siły charakteru, zwykłej ludzkiej moralności" (Sucharski 153; por. Żejmo 193-207).

Nie pozostaje bez znaczenia, że pisarz w chwili aresztowania jest już człowiekiem ukształtowanym, znającym swoje miejsce na ziemi: 
Kiedy mnie aresztowano, miałem trzydzieści dziewięć lat. Byłem ojcem rodziny, człowiekiem materialnie i wewnętrznie niezależnym, przywykłym do szacunku ze strony otoczenia, absolutnie lojalnym obywatelem (Margolin 50).

Ma też świadomość bycia człowiekiem wolnym, odpowiedzialnym, zna swoją wartość, zdążył odkryć istotę swojej egzystencji, swój indywidualny, inteligencki sens życia (Harwas-Napierała 13). Tym bardziej jest mu trudno zaakceptować swoją przynależność do kategorii obozowych podludzi:

Nie byłem (już) żywym człowiekiem tęskniącym za domem, mającym rodzinę i prawo do samookreślenia się [...]. Mur, który z niezrozumiałego dla mnie powodu wyrósł między mną a rodziną, ojczyzną i wolnością, ciężka zmora, od której nie mogłem uciec, niewidoczna sieć, w którą z każdym miesiącem zaplątywałem się coraz mocniej [...] (Margolin 40).

Dodajmy też, że wartość nadrzędną dla narratora, na każdym etapie jego sowieckiej niewoli, stanowiła wolność, ale taka, która sprzyja rozwojowi wolnej myśli. Za nią Margolin tęsknił najbardziej. „Dlaczego pisarzowi wydarto pióro z ręki, spętano myśl uczonego i filozofa?” - pyta narrator, nie godząc się na jego intelektualne zniewolenie (Duda 2014: 226). Niemożność bycia sobą, brak szansy na wystąpienie z głosem protestu i sumienia nazywa Margolin ,najstraszniejszą, największą udręką dla ludzi wolnego ducha” (Margolin 113-114). Świadczy o tym, użyta w tekście niejednokrotnie, metafora duszenia się:

Byłem jednak w niewoli wielkiego mocarstwa, którego nikt nie śmiał kontrolować, które po kryjomu zbudowało dziesięć tysięcy obozów i gnoiło w nich ludzi w najgłębszej tajemnicy przed całym światem! Potworne nieprawdopodobieństwo, koszmarny bezsens, nieludzka podłość tego, co działo się ze mną i milionami takich jak ja, sprawiały, że się po prostu dusiłem (Margolin 216-217).

Nadbudowywanie tożsamości w świecie totalitarnym, jak wynika z relacji Margolina, to niezwykle karkołomne zadanie. „Trzecia wartość” (świadomość własnego rozwoju, konfrontacja z samym sobą), o jakiej pisze Danuta Mostwin (Mostwin 235-236), o ile ma prawo zaistnieć w wielu innych granicznych z punktu widzenia tożsamości sytuacjach, w warunkach totalitarnego zniewolenia praktycznie nie ma szans się wykształcić. Przeszłość i nowe niewolnicze otoczenie, w przypadku Margolina, to dwa zupełnie odmienne światy. Mocno zakorzeniony w żydowskiej, zachodnioeuropejskiej kulturze narrator kategorycznie odrzuca ślepy świat antywartości, fałszu i zakłamania. Dla zakluczonnych, jak czytamy w Podróży:

udawanie i fałsz są niezbędnym warunkiem samoobrony. Należy posłusznie wtórować władzy. Raz na zawsze trzeba zdławić w sobie wewnętrzny głos protestu i sumienia. Nigdy nie wolno być sobą, a to jest najstraszniejsza, największa udręka dla ludzi wolnego ducha (Margolin 113-114). 
Margolin pisze o „chomącie nałożonym na szyję” (Margolin 230), o konieczności wpisania się w ideologiczny schemat, o niebezpieczeństwie utraty człowieczeństwa, którego doświadczył już przy pierwszym spotkaniu z NKWD, od razu, kiedy tylko przekroczył próg budynku milicji w Pińsku: „byliśmy martwi, skreśleni z listy" (Margolin 50-51) - żali się autor.

Margolinowski etos człowieka Zachodu, obywatela „pięknej Europy”, etos pracy intelektualnej, twórczej, rozwojowej runął w jednej chwili - kpiny enkawudzistów, ich wulgarne zachowanie i totalne lekceważenie więźniów, a przede wszystkim unieważnienie polskiego paszportu i izraelskiego obywatelstwa potwierdzają natychmiastową utratę dotychczasowej pozycji społecznej narratora. W tej sytuacji, nawet w łagrze, nawet, jeśli wszyscy są zastraszeni, Margolin nawołuje, aby inteligencja Zachodu podjęła dyskusję i walczyła w obronie uniwersalnych wartości. Strach w tym przypadku nie sprzyja regulowaniu naturalnego zachowania człowieka, o czym pisze Jurij Łotman (Łotman 37), przeciwnie, wynika, jak twierdzi Józef Tischner, z obrony „wewnętrznej prawdy” (Tischner 1997), a w przypadku Margolina także z niezgody na przywykanie, przyzwyczajanie się, na bycie człowiekiem radzieckim:

[...] jak posiedzi pan pięć lat, to przestanie się pan bać. I zostanie człowiekiem radzieckim. Przyzwyczai się pan. Strach przeszkadza się przyzwyczaić. Dlatego właśnie wymiera dziewięćdziesiąt procent takich jak pan, intelektualistów. A dla tych, którzy przeżyją, to nic takiego. Przywykają, pracują i się nie boją (Margolin 168).

W odczuciu Margolina strach przed bezradnością, a nade wszystko przed utratą wolności intelektualnej jest o wiele silniejszy niż strach przed bólem fizycznym. Ale to dobry symptom. Taki właśnie strach, jak twierdzi Józef Bańka, chroni przed utratą godności: umysł ludzki - symbol cywilizacji rozumu - ,produkuje” bez ustanku strach, aby uniknąć trwogi, która mogłaby obalić w człowieku jego „ja”, prowadzić do zniweczenia jego godności (Bańka 1992: 52).

Skoro strach pozwala zweryfikować hierarchię wartości, winduje pojęcia wolności, życia, sprawiedliwości, pokoju (Bańka 1988: 22). Pogrążony w „wiecznym”, „panicznym”, „śmiertelnym” strachu Margolin deinternalizuje wpajane przez ludzi radzieckich antywartości, nie pozwala na dezintegrację kultury, w której tak mocno jest zakorzeniony. Autor potwierdza tym samym swoją wiedzę i erudycję.

Strach w wydaniu Margolina umacnia więzi, sprzyja integracji, krystalizuje podział na „my” i ,oni”, oddziela dobro od zła, niweluje różnice i podziały między ludźmi. Solidarność inteligencji - polskiej i żydowskiej, bo na tę kwestię zwraca uwagę autor, wyczuwa się w tekście przy okazji egzystencjalno-filozoficznych rozmów ze współtowarzyszami niedoli, w których nie ma zgody na socjoprioryzm, gdzie liczy się człowiek z jego myślami, uczuciami i sumieniem (Raźny 
2014: 202). „Bycie z innymi” i doświadczenie drugiego człowieka jest w Podroży kolejnym etapem weryfikacji bycia sobą, poszukiwania wiedzy o sobie samym. W ujęciu fenomenologii antropologicznej ,ja”, żeby stać się sobą, wymaga „ty” (Sariusz-Skąpska 1995: 282-283).

Margolinowska analiza tożsamościowa potwierdza jego bezwzględne stanowisko wobec komunistycznych antywartości, wdrażanych przez reżim nie inaczej, jak tylko siłą i przymusem, przypieczętowuje jego negację komunistycznej propagandy i sowieckiej pseudonauki. Autor nie jest naiwny, od początku pobytu w łagrze wie, że system obozów pracy przymusowej w ZSRR nie jest przypadkiem, ale „logiczną konsekwencją komunizmu” (Margolin 269). Margolin potwierdza przy tym swoją żydowską przynależność, a jednocześnie identyfikuje się z demokratycznym Zachodem.

Wyrażając absolutną krytykę wobec sowieckiego reżimu i kolektywizmu, pisarz sięga do żydowskiej genealogii, gloryfikuje Żydów. Siebie identyfikuje przy tym jako przedstawiciela wielu pokoleń inteligencji żydowskiej, indywidualistów, ludzi piśmiennych i nieznających pańszczyzny, a przez to także jako człowieka trudniej znoszącego łagrowe jarzmo. Sam doświadcza upokorzenia, kiedy w Kruglicy, pełniąc na krótko funkcję inspektora komórki kulturalno-wychowawczej, podczas „rozprowadzenia”, a więc przed wyjściem zeków do pracy, odbywającego się tam wyjątkowo uroczyście, przy akompaniamencie harmonisty i z przemówieniami, miał „wychodzić z czerwonym sztandarem i stać pod trybuną jako żywa dekoracja" (Margolin 223). Obowiązek ten nazywa „zadaniem ponad siły” (Margolin 223) i rezygnuje wówczas z funkcji inspektora, manifestując w ten sposób niezgodę na depersonalizację i utratę wolności poprzez symboliczną deklarację wstąpienia w szeregi zwolenników zbrodniczego systemu. Nie ma wątpliwości, że intelekt czyni życie w obozie bardziej uciążliwym. Zek, który dyskutuje, doprasza się o dodatkową karę (Duda 2008: 61). Margolin jednak, co warto podkreślić, nie poddaje się nawet wtedy, gdy na własnej skórze doświadcza absurdalnej sytuacji, komicznego wręcz odwrócenia obozowych ról. Kiedy naczelnik Łabanow, prawie analfabeta, wysyła Margolina, inteligenta, „nierobociarza” (Margolin 130), do karceru, ten pokornie zapisuje dyktowaną przez Łabanowa decyzję, a następnie odczytuje ją, wysyłając siebie samego do więzienia.

Praca w łagrze, jak twierdzi Margolin, to pogwałcenie ludzkiej natury i zanegowanie podstawowych potrzeb człowieka. Obozy, gdzie ludzie wykształceni wykonują katorżniczy wysiłek przy wyrębie lasu i zmuszani są do wszelkiej innej pracy, zwykle niezgodnej z ich kompetencjami, nazywa Margolin „barbarzyńską profanacją i brakiem szacunku dla ludzkich zdolności i umiejętności” (Margolin 106). Autor jest przekonany, że trud ludzi w niewolniczym wydaniu nigdy nie zaowocuje. 
Pisarz - intelektualista i nonkonformista kategorycznie odrzuca machinę „państwowego niewolnictwa”, opartą na kłamstwie i ucisku, gdzie prym wiedzie pseudonaukowy, sprzeczny logicznie porządek, gdzie demokracja oznacza bezwzględną dyktaturę, postęp - obalenie wszelkich wartości i absolutyzację władzy, zaś nauka - prymitywną wiarę w zaklęcia ideologów (cyt. za: Bielicki 177). Filozof opracowuje swoją koncepcję nienawiści i w ten właśnie sposób chce zmierzyć się ze złem komunizmu, najbardziej traumatycznym doświadczeniem XX wieku (Broda, Kurczak, Waingertner 5). Omawiając krwawą europejską historię, od czasów inkwizycji po akty masowego marksistowskiego terroru i spustoszenie, jakie w Europie zasiał faszyzm i nazizm, Margolin wyraża swój opór wobec nienawiści i kłamstwa, daje wyraz troski o każde ludzkie istnienie. Rosję sowiecką nazywa przy tym „miejscem katorżniczego przymusu i czarnej rozpaczy” (Margolin 277), porównuje ją do ogrodu, z którego z korzeniami wyrywa się kwiaty, a w ich miejsce sieje się nienawiść i zakłamanie.

Filozof teoretyzuje na temat nienawiści i pseudonienawiści, która, choć stanowi jedynie namiastkę tej pierwszej, jej podróbkę, jest bardzo niebezpieczna, szczególnie zaś, gdy przybiera masowy charakter. Do tej kategorii zalicza Margolin pseudonienawiść masowo-dziecięcą (odium infantile), intelektualno-abstrakcyjną (odium intellectuale) i świadomą pseudonienawiść, czyli antynienawiść żołnierza.

Pseudonienawiść dziecięca w jego ocenie to uczucie krótkotrwałe, niestabilne, ale jednocześnie mocne, wybuchowe, spontaniczne. A wspomina o tym uczuciu w kontekście sowieckiego masowego człowieka - infantylnego, uległego, dającego się sterować, który podjudzany przez dyktatorów, ,zimnokrwistych reżyserów i podżegaczy" (Margolin 281), posłusznie wypełnia polecenia złych demiurgów i z największą zaciekłością realizuje ich cele. „Podszczuta masa” (Margolin 281), przekonuje autor, bywa nieprzewidywalna, czasami działa naiwnie, po dziecięcemu, ale jednocześnie jest śmiertelnie niebezpieczna - dzika, nieokiełznana, bezwzględna, brutalna „wyraża się w pogromie, w rozbitych czaszkach i przelewie krwi” (Margolin 281). Ten rodzaj pseudonienawiści jest odwrotnością nienawiści dojrzałej/doskonałej, a więc kontrolowanej, bez emocji, która nie przejawia się wybuchowym zachowaniem, ale każe zachować spokój w najtrudniejszych sytuacjach. Nienawiść dojrzała, często skrywana i tłumiona, najczęściej wyniszcza powoli, ale dogłębnie:

My, dorosłe dzieci, nauczyliśmy się tłumić i regulować przejawy swojej nienawiści, jak radioodbiornik; wyłączać i włączać je jak światło elektryczne. Nasza nienawiść jest potencjalną siłą i dlatego może być uprzejma i spokojna, niczym nie przejawiając się zewnętrznie; biada jednak temu, kto ściska wyciągniętą rękę wroga i idzie obok niego (Margolin 281).

Pseudonienawiść intelektualistów/mędrców, innymi słowy gabinetowa, akademicka lub też teoretyczna, w centrum sytuuje człowieka jako podmiot em- 
piryczny, omawia jego niedoskonałości i wytyka błędy. I chociaż, jak twierdzi Margolin, z założenia głosi szczytne cele, ostatecznie jednak sieje potworne zagrożenie. Jeśli wejdzie w użycie mas i silnych jednostek i poddana zostanie błędnej interpretacji, łatwo staje się przyczynkiem do wojen i okrutnych w skutkach ideologii.

Trzeci rodzaj pseudonienawiści to antynienawiść walczących w słusznej sprawie (odium nationale). Zdefiniowanie tego rodzaju pseudonienawiści przychodzi Margolinowi z największą łatwością. Jest ona czytelna i najmniej skomplikowana. Ten rodzaj fałszywej nienawiści jednoznacznie wiąże autor $\mathrm{z}$ atakiem wroga i odpowiedzią na skutki tego ataku.

Rozważania Margolina na temat pseudonienawiści stanowią jedynie podłoże do głębszej refleksji na temat nienawiści w formie czystej i pierwotnej, a jednocześnie najbardziej niebezpiecznej. Ta, jak twierdzi filozof, nie wynika z zewnętrznych problemów - wtedy mielibyśmy do czynienia z odium nationale lecz z indywidualnych defektów, ludzkich słabości, z urojonych i nieracjonalnych szaleńczych zachowań, a także z braku równowagi duchowej. „Chodzi o zaciekłą, potworną, ale całkowicie obiektywną siłę destrukcyjną, wynikającą z beznadziejnej próby budowania własnej przeklętej egzystencji na nieszczęściu i śmierci innych" - pisze Margolin (Margolin 285).

Podczas, gdy Zinowiew utrzymuje, że postawy komunizmu szczepią reprezentanci najniższych klas społecznych, a władza jedynie umiejętnie wspiera te działania (Suchanek 1993: 218), Margolin na szczycie piramidy nienawiści (por. Borejsza 25) stawia inspiratora, którego nazywa „uosobieniem nienawiści” (Margolin 283). To właśnie przywódców, pojedyncze patologiczne jednostki, które niszczą życie innych i kradną im wolność, tworząc bestialskie ideologie, oskarża o napędzanie mechanizmu nienawiści.

Podsumowując jedynie wstępne omówienie teorii nienawiści Margolina - Podróż jest bowiem doskonałym materiałem do dalszych, dogłębnych badań w tym zakresie - podkreślić należy, że o ile nienawiść stanowi według autora siłę najbardziej destrukcyjną - zabija człowieka, gardzi wolną myślą i odrzuca intelekt rozum to jej opozycja, pozwala odróżnić dobro od zła, jednoczy ludzi w walce, wskazuje właściwą drogę.

Warto dodać, że Margolin zawsze ocenia świat racjonalnie, nie emocjonalnie, zawsze z największą satysfakcją tryumfuje, gdy w sytuacjach obozowej traumy, bezsilności, zezwierzęcenia potrafi zapanować nad nienawiścią, gdy, jak sam mówi, jest w stanie ją ogarnąc i poddać pod osąd rozumu. Jego bogata w konteksty filozoficzne relacja momentami nasuwa skojarzenia z opisem kołymskich doświadczeń Filipa Istnera, żydowskiego poety, urodzonego w 1912 roku we Lwowie. Narrator, poszukując sensu własnych traumatycznych doznań, czasami przypomina istnerowskiego „człowieka samotnego, zasmuconego złem” (Famul- 
ska 2012). Z tą jednak różnicą, że Margolin nie jest „mędrcem-pesymistą” (Famulska 2012), ale racjonalnie myślącym humanistą i intelektualistą, który - będąc uczestnikiem łagrowej rzeczywistości - jest jednocześnie doskonałym jej interpretatorem.

\section{Bibliografia}

Abassy, Małgorzata. Irańska inteligencja w XIX wieku i Rewolucja Konstytucyjna (1905-1911). Kraków, Wydawnictwo Uniwersytetu Jagiellońskiego, 2010.

Adorno, Theodor, Max Horkheimer. Dialektyka Oświecenia. Przeł. Małgorzata Łukasiewicz. Warszawa, IFiS PAN, 1994.

Bańka, Józef. Cywilizacja diatymiczna, czyli świat jako strach i łup. Katowice, Wydawnictwo Naukowe „Sląsk”, 1986.

Bańka, Józef. Medytacje parmenidiańskie o pierwszej filozofii: recentywizm i pannyngeneza. Katowice, Wydawnictwo Uniwersytetu Śląskiego, 1992.

Bielicki, Paweł. „Żelazna kurtyna jako aspekt sowietyzacji Europy Wschodniej w latach 19491953”. Studia z Dziejów Rosji i Europy Środkowo-Wschodniej, t. 52, 1, 2017, s. 175-200.

Bittner, Ireneusz. Współczesna antropologia filozoficzna. Łódź, Wydawnictwo Uniwersytetu Łódzkiego, 1999.

Borejsza, Jerzy. Szkoły nienawiści: historia faszyzmów europejskich 1919-1945. Wrocław, Zakład Narodowy im. Ossolińskich, 2000.

Broda, Marian, Justyna Kurczak, Przemysław Waingertner. Komunizm w Rosji i jego polskie interpretacje. Łódź, Ibidem, 2006.

Duda, Katarzyna. „Tożsamość (pseudo)naukowców w państwie totalitarnym (na przykładzie wybranych tekstów literackich)". Tożsamość, indywidualizm, wspólnotowość w kulturze rosyjskiej. Red. Anna Raźny. Kraków, Wydawnictwo Uniwersytetu Jagiellońskiego, 2014, s. 213-227.

Duda, Katarzyna. „Współczesna literatura rosyjska wobec historii”. Prace Komisji Kultury Stowian PAU. Kultura i Polityka. T. VII. Red. Lucjan Suchanek. Kraków, Polska Akademia Umiejętności, 2008, s. 45-63.

Famulska, Karolina. Filip Istner (1912-1990). Web. 02.09.2019. https://www.bu.umk.pl/Archiwum_Emigracji/gazeta/ae_16/29_Famulska.pdf.

Harwas-Napierała, Barbara. „Tożsamość jednostki w epoce współczesnych przemian”. Tożsamość a współczesność. Red. Barbara Harwas-Napierała, Hanna Liberska. Poznań, Wydawnictwo Naukowe UAM, 2007, s. 11-23.

Haumann, Heiko. Historia Żydów w Europie Środkowej i Wschodniej. Warszawa, Wydawnictwo Adamantan, 2000.

Kierkegaard, Soren. Choroba na śmierć. Bojaźń i drżenie. Przeł. Jarosław Iwaszkiewicz. Warszawa, PWN, 1972.

Kotarbiński, Tadeusz. Elementy teorii poznania, logiki formalnej i metodologii nauk. Warszawa, Wydawnictwo Polskiej Akademii Nauk, 1995.

Kozielecki, Józef. Psychologiczna teoria samowiedzy. Warszawa, Wydawnictwo Naukowe PWN, 1986.

Lotman, Urij. Stat'i po tipologii kul'tury. Tartu, Izdatel'stvo Tartuskogo gosudarstvennogo universiteta, 1970. 
Margolin, Julius. Podróż do krainy zeków. Przeł. Jerzy Czech. Wołowiec, Wydawnictwo Czarne, 2013.

Mostwin, Danuta. Trzecia wartość. Lublin, Redakcja Wydawnictw Katolickiego Uniwersytetu Lubelskiego, 1995.

Neuner, Gerhart. Kształtowanie osobowości socjalistycznej. Warszawa, Wydawnictwa Szkolne i Pedagogiczne, 1979.

Nikitorowicz, Jerzy. Pogranicze, tożsamość, edukacja międzykulturowa. Białystok, Trans Humana, 1995.

Pietrzycka-Bohosiewicz, Krystyna. Historia zapisana w człowieku. Wybrane problemy wolnej literatury rosyjskiej. Kraków, Collegium Columbinum, 2008.

Raźny, Anna. Amerykański globalizm. Web. 18.09.2019. http://wsercupolska.org/wsp1/index.php/ warto-przeczyta/8231-8231.

Raźny, Anna. „Tożsamość osobowa w Gułagu”. Tożsamość, indywidualizm, wspólnotowość w kulturze rosyjskiej. Red. Anna Raźny. Kraków, Wydawnictwo Uniwersytetu Jagiellońskiego, 2014, s. 202-212.

Ricoeur, Paul. O sobie samym jako innym. Przeł. Bogdan Chełstowski. Warszawa, Wydawnictwo Naukowe PWN, 2005.

Sariusz-Skąpska, Izabela. Polscy świadkowie GUŁagu. Literatura łagrowa 1939-1989. Kraków, Universitas, 1995.

Suchanek, Lucjan. Homo sovieticus: świetlana przyszłość, gnijacy Zachód. Pisarstwo Aleksandra Zinowiewa. Kraków, Wydawnictwo Uniwersytetu Jagiellońskiego, 1999.

Suchanek, Lucjan. „Utopia świetlanej przyszłości. A. Zinowiew”. Emigracja i tamizdat. Szkice o wspótczesnej prozie rosyjskiej. Red. Lucjan Suchanek. Kraków, Universitas, 1993, s. 205224.

Sucharski, Tadeusz. Polskie poszukiwania ,innej” Rosji. O nurcie rosyjskim w literaturze Drugiej Emigracji. Gdańsk, Słowo/obraz terytoria, 2008.

Szołtysek, Adolf. Filozofia myślenia. Ontologiczne, językowe i metodologiczne determinanty myślenia. Kraków, Impuls, 2011.

Tischner, Józef. Krótki przewodnik po życiu. Web. 20.09.2019. https://vvqglamtroop.files.wordpress.com/2018/01/krotki-przewodnik-po-zyciu.pdf.

Ubertowska, Aleksandra. Świadectwo - trauma - glos. Literackie reprezentacje Holokaustu. Kraków, Universitas, 2007.

Wiśniakowska, Lidia. Słownik wyrazów obcych. Warszawa, Wydawnictwo Naukowe PWN, 2005.

Zinowiew, Aleksander. Homo sovieticus. Przeł. Stanisław Deja. Londyn, Polonia, 1984.

Żejmo, Bożena. „Aleksandr Solženicyn i Varlam Šalamov : odin opyt, dve pravdy”. Aleksander Solżenicyn i rosyjska emigracja. Red. Magdalena Dąbrowska, Piotr Głuszkowski. WarszawaTorun, Pracownia Wydawnicza Eikon, 2018, s. 193-206. 
